特集 食品研究の 新領域を さぐる

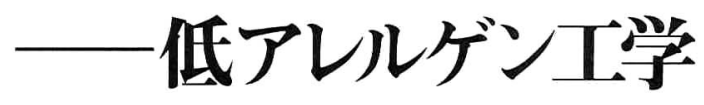

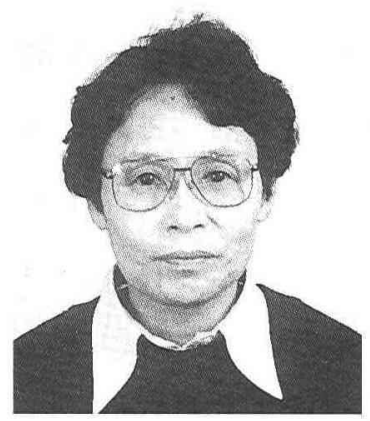

渡辺道子

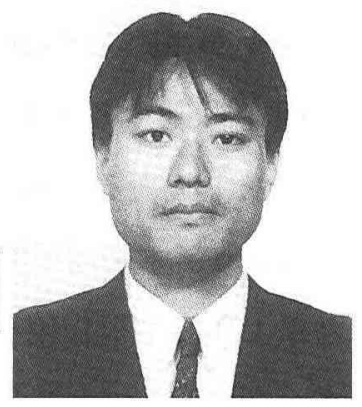

田辺創一
近年、アレルギー患者が世界的に増加の傾向に あり、とくに先進国でその傾向が強い。食物アレ ルギーは、捸取した食物 (より正確にはアレルゲ ンと呼ばれる特定の食品成分) に過敏反応を示す 病状である。アレルゲンはタンパク質であること が多い。鷄卵、牛乳、大豆、米扰よ゙゙麦にアレ ルゲンが存在しているのはよく知られたことであ り、これらの食品を食べ続けるとアレルギーの発 症がしばしば観察される。

このように食物アレルギーはすでに国際的な関 心事なのである。日本でも最近、食物アレルギー が深刻な問題となっている。この現状を踏まえて、 厚生省の特別研究班などで医学的立場からのその 対応策が研究されている。

免疫学的には、アレルギーは抗体の一種である 免疫グロブリン $\mathrm{E}(\mathrm{IgE})$ の血清レベルが異常に高ま って、これが肥満細胞上でアレルゲンと結合する と、この細胞からヒスタミンなどの化学物質が放 出され、皮膚に炎症 (アトピー性皮膚炎) を起こす 病態である。このうち、穀物アレルギーは、パン、 麺類、クッキー、ケーキ、ソース類、酒類など穀
物製品を継続して掑取した場合に起こるアレルギ 一反応である。

その主な症状は、アトピー性皮膚炎で、穀物製 品を撕取してから短時間に発症し、水痘やかゆみ の症状が原因食品を止めるまで続く。長い歴史を 通して㩯物製品の食べ方が固定化されている国々 では、穀物アレルギーは深刻な社会問題となって いる。驚くべきことに、日本では米が、最も発症 頻度の高いアレルギー原因食品である卵白に次い で、第二のアレルギー原因食品にランクされてい るという。しかしながら、穀物になぜ感作する人 が最近増えてきたかを伝える文献はない。

このような背景から、日本人の主食である小麦 と米のアレルゲンの構造と、既に開発されている あるいは開発途上にある低アレルゲン化穀物食品 の特質を、筆者らの研究を中心に、食品学の見地 から概説してみたい。

\section{1. 小麦}

小麦アレルギーは世界的な関心事であるにも かかわらず、その主要アレルゲンについては長 
い間不明のままであった。最初に小麦アレルゲ ンを明らかにしたのは筆者らの研究グループで あって、小麦粉を希薄な塩溶液に溶ける(塩溶性) 成分と溶けない（塩不溶性）成分に分け、小麦ア レルギー患者の抗体との結合性から塩不溶性成 分が主なアレルゲンであることを見い出した。 小麦粉から塩不溶性成分の主体であるグルテン をタンパク質分解酵素で加水分解したものから アレルゲン性ペプチドを単離した。アミノ酸配 列解析の結果、このペプチドは30残基のアミノ 酸から成り、Ser-Gln-Gln-Gln-Gln-Pro-Pro-PheSer-Gln-Gln-Gln-Pro-Pro-Phe-Ser-Gln-Gln-Gln-GlnPro-Pro-Phe-Ser-GIn-GIn-Gln-Pro-Pro-Phe (Serは セリン残基、Glnはグルタミン残基、Proはプロリ ン残基、Pheはフェニルアラニン残基)であること がわかった ${ }^{(1)}$ 。

アミノ酸配列の類似性を調べた結果、このペプチ ドは低分子量グルテニンと呼ばれるタンパク質に由 来していた。興味深いのは、パン酵母のタンパク質 とアミノ酸配列が似ていることである。このことは、 小麦アレルギー患者用パンを作る工程で、パン酵母 を使用してはならないことを意味している。

この30アミノ酸残基のペプチドは、IgEに結合す るのに必須な部位（Gln-Gln-Gln-Pro-Pro）をもっ ている。興味深いことに、小麦タンパク質そのも のを酵素で部分的に分解することにより、颃えらく このペプチドを含むであろうタンパク質分解物を 調製することができ、しかもそれは免疫不応答効 果 (ハプテン効果) を示し、アレルギー発症を予防 できる可能性が示唆された ${ }^{(2)}$ 。

最近になって、小麦には多糖抗原が存在すること
がわかった。この抗原はグルコースとマンノースか ら成る多糖で、多糖分解酵素で加水分解されてア レルゲン性がなくなる。

そこで、多糖分解酵素およびタンパク質分解酵 素で処理して低アレルゲン化小麦粉を開発した。 まず、多糖分解酵素処理してからタンパク質分解 酵素処理する工程であるが、タンパク質分解酵素 としてはタイプの異なる数種類の酵素の混合物が 低アレルゲン化に有効であった。特定の条件下で これらの酵素を小麦粉に作用させることによっ て、好ましい加工特性を温存したまま低アレルゲ ン化された小麦粉を得ることができた。

さらに、臨床試験に向けて嗜好性の高い食品が 望まれるために、低アレルゲン化小麦粉を実際の 食品に加工した。低アレルゲン化小麦粉はどろど ろした液体であるが、これにオリゴ糖、界面活性 剂、食塩を配合し、押し出し加工してパスタ様の 麺を作製した。このパスタ様の湎は市販のスパゲ ッティと類似しており、レトルト加工と冷凍保存 が可能であり、賞味期間を長くすることができる。 同様の材料と炭酸水素ナトリウムを配合して、イ ングリッシュ・マフィンに似た低アレルゲン化パ ンを作製することにも成功している。

他に、患者がおいしく食べてくれるような低アレ ルゲン食品をも開発した。低アレルゲン化処理した 小麦粉に調味料、膨化剂、油脂、界面活性剂などを 配合して低アレルゲン化カップケーキとウエファー を作製した。製品の外観を図に示す。一連の低アレ ルゲン化工程は、本年、工業化され、一般消費者向 けの機能性食品として製品化される予定である。 


\section{2. 米}

米の主要アレルゲンは塩溶性タンパク質であ る。このタンパク質は通常のジャポニカ種の米に は少ししか含まれていないが、耐熱性で、通常の 炊飯条件ではアレルゲンとしての性質は失われな い。したがって、普通の米飯を食べると、免疫学 的に活性な形でこのタンパク質を摃取しているこ とになる。主要な米アレルゲンは小型のタンパク 質で ${ }^{(3)}$ 、消化管酵素にある程度耐性で、一部では あるが高分子のまま吸収され、アレルギーを引き 起こしてしまうことを意味している。

筆者らのグループは、低アレルゲン化米の製 造方法を開発した。工程は、タンパク質分解酵 素で主要アレルゲンタンパク質を水解するとい うものである。日本では、米を粒のまま食べる 習慣があるため、米粒に直接、酵素処理するこ とにした。新米の精白米を食用界面活性剤と酵 素を溶かしこんだ緩衝液に浸漬した。界面活性
剂を用いたのは、溶液の表面張力を下げて酵素 が米粒の肧乳に浸透しやすくするためである。 脱気も酵素の浸透に効果的であった。酵素反応 物は水洗、酸処理後、反応生成物や酵素を流水で よく洗い流した。最後に、米粒を軽く蒸煮して、 表面のでんぷんを糊化させて機械的な強度を高 め、砕米化を防いだ。主要アレルゲンを含む塩溶 性タンパク質はほとんど完全に消失していたが、 タンパク質の大部分を占める塩不溶性タンパク質 は半量以上が残存していることが判明した。

このようなほぼ特異的ともいえるタンパク質 分解は、塩溶性タンパク質が米種子の細胞質に 存在していて、米粒に浸透してきたタンパク質 分解酵素の作用を受けやすいのに反して、塩不 溶性のタンパク質は細胞のプロティンボデイと 呼ばれる顆粒に蓄えられていて、酵素作用を受 けにくいからと考えられる。この結果は、低ア レルゲン化米でもタンパク質の大部分が未分解
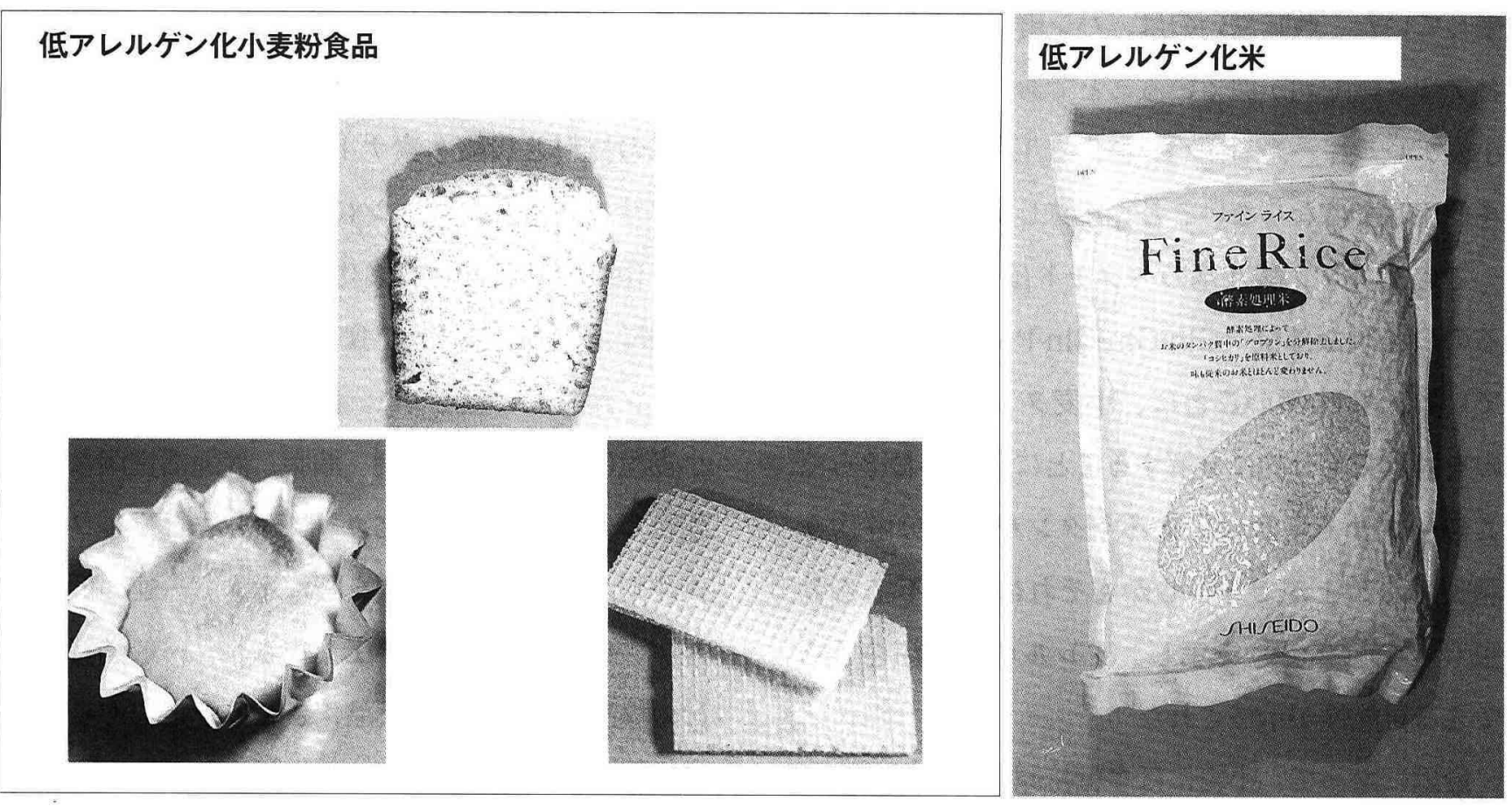
のまま貯留されていることを意味し、栄養学的 にも重要なことといえる。

臨床評価には13の病院の16名の医師が参加し、 41名の米起因性アトピー性皮膚炎患者有志の毎日 の食事で、普通の米の代わりに低アレルゲン化米 を長期にわたって与えたときの効果が調べられ

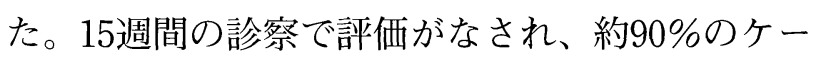
スで低アレルゲン化米は有効であると評価がくだ されている(4)。この工程は、多少の条件変更がな されて工業化されている。製品は、「ファインラ イス」という商品名で市場に登場し、1993年6月1 日、厚生省によって特定保健用食品第1号として 認可された (図)。以来、何千もの病院で患者に供 給され、概して有効であるという。

日本では、先天的あるいは後天的に米に過敏な 幼児や成人がいて、毎日のメニューから米を除去 しないとアレルギーの症状がでてしまう。こうし た保因者でも普通の食習慣にしたがって食事がで きるのであるから、低アレルゲン化米は大きな福 音である。

食物アレルギーの一般的予防法については、
医学・薬学の分野で精力的な研究が進められて いる。とりわけ、腸管免疫寬容という生体機序 を利用したアレルギー予防法には大きな期待が もたれている。一方、食品学分野では、個々の 食品からそれぞれのアレルゲンを除去する方向 での研究が行われており、とくに酵素分解法の 活用は上述したようにきわめて実用性が高く、 工業規模での低アレルゲン化が可能である。す でにミルクからアレルゲンを除去するための酵 素分解法は以前から行われており、低アレルゲ ンミルクペプチドが製品化されている。将来は、 育種の段階から低アレルゲン化をねらった穀物 や乳製品は開発されると予想される。食品学は、 病気の予防を目的とする食品を開発する新時代 に突入している。なかでも、予防は最も緊急な 課題の1つになると思っている。

\section{渡辺 道子（わたなべみちこ 1938年生） \\ 東京学藝大学教授、農学博士}

専門：食品加工学

田辺 創一（たなべそういち 1967年生）

東京学藝大学助手、農学博士

専門：食品生化学

(1) S. Tanabe, S. Arai, Y. Yanagihara, H. Mita, K. Takahashi, and M. Watanabe, Biochem. Biophys. Res. Commun, 219, 290-293 (1996).

(2) S. Tanabe, S. Tesaki, Y. Yanagihara, H. Mita, K. Takahashi, S. Arai, and M. Watanabe, Biochem. Biophys. Res. Commun, 223, 492-495 (1996).

(3) H. Izumi, T. Adachi, N. Fujii, T. Matsuda, R. Nakamura, K. Tanaka, A. Urisu, and Y. Kurosawa, FEBS Lett., 302, 213-216 (1992).

(4) M. Watanabe, Trends Food Sci. Technol., 4, 125-128 (1993). 